\title{
Effect of organic and chemical fertilization on growth performance, phytoplankton biomass and fish production in carp polyculture system
}

\author{
Mohsen Saleh Hussein \\ Department of Animal Production (Fish Production), Faculty of Agriculture, \\ Al-Azhar University, Egypt.
}

\section{ABSTRACT}

This study reports on the effect of organic (sheep and cow manure), and chemical fertilizers, on the phytoplankton, primary productivity and aquaculture production in the cultivation of carp in semi-intensive earthen ponds. The average biomass final $(\mathrm{kg})$ were $1687.4,1948.8$ and $2370.6 \mathrm{~kg} / \mathrm{fed}$. in $\mathrm{T} 1, \mathrm{~T} 2$ and $\mathrm{T} 3$, respectively. Treatment with chemical fertilizers was found to present the highest yield with $11.57 \pm 0.67 \mathrm{~kg} / \mathrm{fed}$./day. It was followed by treatment with cow manure $(9.20 \pm 1.24 \mathrm{~kg} / \mathrm{fed} . /$ day $)$ and sheep manure $(7.79 \pm 1.95 \mathrm{~kg} / \mathrm{fed} . /$ day $)$. Concentrations of phytoplankton were significantly $(\mathrm{p}<0.05)$ higher in ponds fertilized with sheep and cow manures $(1,824,726$ and $1,416,416$ cells $/ \mathrm{ml}$, respectively) than in ponds fertilized with chemical fertilizer $(1,084,630$ cells $/ \mathrm{ml})$. All of water quality parameters $(\mathrm{P}>0.05)$, were within the acceptable range during the present study.

In general, conditions were adequate to obtain high yields without the commercial feed, therefore organic fertilizers application can be recommended, due to its availability and low costs.

Keywords: polyculture, chemical and organic fertilizers, water quality, carp.

\section{INTRODUCTION}

Fish culture with manures as the main nutritional input is a long-time practice in China (Tang, 1970). Nevertheless the wide use of mineral fertilizers in industrialized countries; is supply limited and even expensive in many low developed nations.

Presently fish culture mainly depends on the application of organic fertilizers and to some extent on inorganic ones. Fertilization enhances phytoplankton productivity in rearing and stocking ponds (New and Fedoruk, 2003; Bhakta et al., 2004, 2006). Phytoplankton and zooplankton are rich sources of protein (40-60\%) on dry weight basis which is sufficient for fish growth at low stocking densities (Silva and Anderson, 1995; Tabinda and Ayub, 2009, 2010; Sun et al., 2010).

Animal manures, which are generally plentiful worldwide, constitute a low- to intermediate-cost nutrient source. The study of fertilization in the carp polyculture has focused to address issues about the effect of chemical and organic fertilization on water quality and growth of carp (Vromant et al., 2002; Dhawan, 2002).The water quality and fish production in ponds with or without organic fertilization (Nikolova et al., 2008a and 2008b) and the effect of supplemental feeding on water quality and structure of phytoplankton in fertilized earthen ponds cultivated with Tilapia and carp (Abdel- Tawwab et al., 2007 ).

Among the new trends in fish culture, integrated semi-intensive system seems to be the most acceptable, due to the fact that various agricultural wastes and low value feedstuff can be utilized as a cost-effective source of fish feed. Fertilizers increase the level of primary productivity, dissolved oxygen, $\mathrm{pH}$ and total phosphorus (Qin et al.,1995).They increase fish production without risk of dietary diseases and also play an important role in 
the formation of soil structure. The growth of fish is strongly correlated with increase of phytoplankton and zooplankton productivity as a result of fertilization. Under polyculture system, the use of organic and inorganic fertilizers provides basic nutrients and elements required for the production of phytoplankton and zooplankton which serve as a major source of food for fish (Javed et al., 1992).

The first link in food chains within land waters are phytoplankton and are an indicator of production level. Within these environments,fish ponds with a high abundance characterized as highly eutrophic systems primary productivity, and promote the growth of fish in a polyculture fish, particularly filter feeders. Infertilized ponds, the increase of phytoplankton is due to the intensity and type, as productivity increases with careful management, with a continuous and controlled addition of inorganic and / or organic fertilizers to produce autotrophic organisms. (Hepher and Pruginin, 1981; Hussein, 2009; Ponce Palafox, 2010).

Purpose of all these steps and precautionary measures is to enhance the present level of fish production and provide desired quality and required quantity of protein to the carcuss masses.

There have been several works research regarding the development of phytoplankton, was described some effects of different types of fertilizers in ponds, its composition, growth, relationships between the groups and their dynamics in dailyand monthly fluctuations, indicating that they depend on various factors, including predation, the incidence light and nutrient type (Wilkins and Piedrahita, 1988; Moustaka and Nikolaidis, 1992; Vadas, 1992; Hussein, 2009; Ponce Palafox, 2010). It is important to understand diversity wealth, other characteristics of phytoplankton and the function performed by the channels trophic polyculture systems. In the present study, the effect of organic and chemical fertilizers on phytoplankton biomass and fish production was evaluated in ponds stocked with carp polyculture.

The production of fish ponds depends mainly on the vegetation, which is dependent on the nutrients in ponds. It is not possible to increase the production of cultivated fish by giving them the greater quantities of natural food directly. Organic manures and chemical fertilizers can be used to increase the planktonic biomass, on which fish mainly feeds. It stimulates the growth of natural food by providing essential elements, which are utilized by the phyto-and zooplanktons. The fertilization in fish farming is to improve water quality and to increase the variety and quantity of phytoplankton and zooplankton, which eventually leads to high fish yield and economic returns. The ultimate goal of fertilization is to achieve suitable environmental conditions for the production of natural food for fish, but in comparison with organic manure, fertilizers increase the level of primary productivity, algae abundance, dissolved oxygen, $\mathrm{pH}$ and total phosphates (Afzal et al., 2007; Hussein (2009); Jana et al., 2001; Ponce Palafox, 2010).

The objective of the present experiment was to evaluate the effects of fertilizer types on growth performance in terms of average body weight, specific growth rate and total fish production of common carp, grass carp, bighead carp and silver carp, water quality parameters and economic returns under polyculture in semi-intensive fish culture system at Serow Fish Farm, under different treatments.

\section{MATERIALS AND METHODS}

This work was carried out in nine earthen ponds (each of $4200 \mathrm{~m}^{2}$ surface area) located at Serow Fish Farm, National Institute of Oceanography and Fisheries, Dakahlia Governorate, Egypt. These ponds were firstly drained and cleaned, then supplied with drainage freshwater from El-Serow drainage canal to a depth of 1.2-1.5 m. The 
experimental period lasted for 6 months (180 days, initiated on first of May till first of November).

Pond preparation: Before stocking, all the ponds were sun dried for fifteen days. Essential precautionary measures were taken to screen the water inlets to avoid the entry of intruders or exit of the fish from ponds. After one week of taking these steps, each pond was watered up to $1.5 \mathrm{~m}$ and this water level was maintained throughout the experimental period. All the ponds were fertilized with organic manure (cow manure) as a start dose to stimulate the productivity of the ponds.

Stocking of fish species in experimental ponds: Two weeks after manuring and ponds had been filled with water, each pond (with an area of one feddan), under fish polyculture system, was stocked randomly with four species of grass carp, Ctenopharyngodon idella (20\%), silver carp, Hypophthalmichthys molitrix (15\%), bighead carp, Aristichthys nobilis (15\%), and common carp, Cyprinus carpio (50\%), at one stocking rate (10,000 fishes/feddan).

The average initial body weight was recorded. There were no significant differences among treatments in the size of fish at stocking. Fingerlingscommon of carp used for the present study were collected locally from the Serow Fish Farm. Grass carp, Silver carp and bighead carp fingerlings were obtained from Abbassa Fish Hatchery belonging to the General Authority for Fish Resources Development (GAFRD), Ministry of Agriculture, Egypt.

Fertilization: The present fish ponds received sheep manure (2,6,9 ponds), cow manure (1,3,8 ponds) and mineral fertilizer (urea and triple superphosphate) (4,5,7 ponds) at twice daily intervals at $09.00 \mathrm{~h}$ and $14.00 \mathrm{~h}$,from Saturday to Thursday for a period of six months.

Approximate chemical composition of organic (cow manure and sheep manure) and inorganic (Urea and TSP) fertilizers concentrations and nutrient applications rates as $\mathrm{kg} /$ pond during the experimental period(\% dry matter basis, Mean $\pm \mathrm{SE}$ ) used are given in Table (1), and was estimated according to AOAC (1994).

Table 1: Approximate chemical composition of organic (cow manure and sheep manure) and inorganic (Urea and TSP) fertilizers concentrations (\% dry matter basis, Mean \pm SE)

\begin{tabular}{|l|l|l|l|}
\hline \multirow{2}{*}{ Treatments } & \multicolumn{2}{|c|}{ Organic fertilizer } & \multicolumn{1}{|c|}{$\begin{array}{c}\text { Inorganic fertilizer } \\
\text { (Urea+TSP) }\end{array}$} \\
\cline { 2 - 3 } & \multicolumn{1}{|c|}{ Sheep manure Cow manure } & $\left(46 \% \mathrm{~N}+46 \% \mathrm{P}_{2} \mathrm{O}_{5}\right)$ \\
\cline { 2 - 3 } & $(1.6 \% \mathrm{~N}+0.75 \% \mathrm{P})$ & $(1.7 \% \mathrm{~N}+0.45 \% \mathrm{P})$ & - \\
Dry matter & $90.21 \pm 0.10$ & $89.11 \pm 0.14$ & 46.0 \\
Nitrogen $(\%)$ & $1.6 \pm 0.11$ & $1.7 \pm 0.04$ & 46.0 \\
Phosphorus $(\%)$ & $0.75 \pm 0.02$ & $0.45 \pm 0.01$ & 1 \\
$\mathrm{~N}: \mathrm{P}$ ratio & $2.13 \pm 0.21$ & $3.78 \pm 0.23$ & $146 \pm 27$ \\
$\mathrm{Kg} /$ fed/180 days & $2520 \pm 0.22$ & $5040 \pm 0.22$ & \\
\hline
\end{tabular}

The amount of organic and inorganic fertilizers was calculated on N-P equivalence of $0.2 \mathrm{~g} \mathrm{~N}$ and $0.01 \mathrm{P} / 100 \mathrm{~g}$ wet body weight of fish (Islam, 2002; Hussein 1995). Inorganic fertilizers (Urea with $46.5 \% \mathrm{~N}$ and TSP $46 \% \mathrm{P}$ ) were used at a rate of $0.345 \mathrm{~kg}$ P/feddan $(0.75 \mathrm{~kg}$ TSP/fed.) and $2.5 \mathrm{~kg} \mathrm{~N} / \mathrm{feddan}(5.3 \mathrm{~kg}$ urea/fed.0) every two weeks, after stocking in water in plastic barrels and broadcasting this mixture over the pond water surface (Hussein,1995).Cow and sheep manures were broadcast over the ponds surface; volumes of manure used were 0.7 to $1.4 \mathrm{~m}^{3} /$ fed./day (14.0 to $28.0 \mathrm{~kg}$ dry matter/fed./day) (Hussein, 2009). Three treatments were randomly applied with three replicates each as follows:

$\mathrm{T}_{1}(1,2,3$ ponds $)=$ organic fertilizers (sheep manure), $\mathrm{T}_{2}(4,5,6$ ponds $)=$ organic fertilizers (cow manure) and $\mathrm{T}_{3}(7,8,9$ ponds $)=$ inorganic fertilizers $(\mathrm{Ch}$.$) , urea (46 \% \mathrm{~N})$ 
and triple superphosphate $\left(46 \% \mathrm{P}_{2} \mathrm{O}_{5}\right)$. In the present study, all the experimental ponds received the same quantity of $\mathrm{N}$ and $\mathrm{P}$ with the different sources.

Fish growth parameters: After every one month, fish sample for each weight (monthly) were 400 fish / treatment weight collectively, cultured fish species were captured randomly by using drag net from each experimental treatment and released back into their respective ponds after recording the data for wet body weight (WBW). After one month interval, on the basis of WBW, amount of organic and inorganic fertilizers added in fish ponds were determined for each treatment.

Wet body weight gain (wWG) (g) = mean final fish wWt.(g) - mean initial fish wWt.(g). AGR (g/ day) = Final fish wt. (g) - Initial fish wt. (g)/ time (days).

Total fish production under different treatments: At the end of the experiment, total harvested fish of experimental fish species were weighed to calculate the total fish production.

Water and fish samples: The ponds were assigned to each treatment in a randomized design with three replicates per treatment. At the outlet of each pond variables of water quality and productivity were determined. Water samples were collected every 15 days from each pond from the middle of water column by a closed sample bottle and opened in the desired depth. This procedure was done in five different spots in each pond, the samples were mixed in a plastic bucket and 1 liter sample was taken as a representative water sample of each pond. These samples were taken 1 week after fertilizer application. At the time of sampling, water temperature, dissolved oxygen were measured in addition to their measurements two times weekly. Water temperature and dissolved oxygen were measured at $900 \mathrm{~h}$, using dissolved oxygen meter model Orion $835 \mathrm{~A}, \mathrm{pH}$ was measured by Acumen 25 meter, total alkalinity, orthophosphate $\left(\mathrm{Po}_{4}\right)$ nitrate $\left(\mathrm{No}_{3}\right)$, total ammonia nitrogen (TAN; $\mathrm{NH}_{3 / 4}$ ) were determined according to Boyd (1990) and APHA (1985).

Primary productivity, primary gross, respiration and phytoplankton biomass were measured every 15 days, using the procedures suggested by Boyd (1990) and Arredondo-Figueroa and Ponce-Palafox (1998).

Statistical analysis: Values for fish yield and plankton biomass were determined for each pond, according to EIFAC (1980) guidelines. Analysis of variance was used to detect significant differences in biological factors between treatments (Duncan, 1955). Treatments were compared using the Tukey's test. The analyses were done using SAS (2005), (ver.9.1, SAS institute incorporation, Cary, NC27513USA for Windows package).

\section{RESULTS AND DISCUSSION}

As shown in Table (2) all of water quality parameters differ among treatments $(\mathrm{P}>0.05)$. All ponds were within the acceptable range of water quality parameters during the study.

As shown in Table (2), average water temperatures during the experiment ranged from $27.2 \pm 0.12$ to $28.4 \pm 0.11{ }^{\circ} \mathrm{C}$. No significant differences $(\mathrm{P} \leq 0.05)$ were observed in water temperature among treatments. The highest value of water temperature in $\mathrm{T} 1(28.4 \pm 0.11)$ received sheep manure, may be attributed to the increase in organic matter contents of this pond that may lead to temperature increase.

This range was beneficial to fish culture and these are in agreement with results of Hussein and Abdel-Hakim(2003); Hussein (2009) and Ponce Palafox (2010).Results revealed that carp need at least $18{ }^{\circ} \mathrm{C}$ minimum temperature for growth (Arredondo-Figueroa and Juarez, 1986), so there was no negative effect on the growth of polyculture.After temperature, dissolved oxygen concentrations of 
water is the most important variable in the pond culture system (Arredondo-Figueroa and Ponce-Palafox, 1998).

Table 2: Monthly average of water quality parameters and productivity data in carp polyculture in earthen ponds ( in 180 days, mean $\pm \mathrm{SE}$ ).

\begin{tabular}{|l|l|l|l|}
\hline Parameter & \multicolumn{1}{c|}{$\begin{array}{c}\mathrm{T} 1 \\
\text { Sheep manure }\end{array}$} & $\begin{array}{c}\mathrm{T} \\
\text { Cow manure }\end{array}$ & $\begin{array}{c}\text { T3 } \\
\text { Inorganic fertilizer }\end{array}$ \\
\hline Water temperature. $\left({ }^{0} \mathrm{C}\right)$ & $28.4 \pm 0.11^{\mathrm{a}}$ & $27.9 \pm 0.14^{\mathrm{a}}$ & $27.2 \pm 0.12^{\mathrm{a}}$ \\
\hline Dissolved Oxygen $(\mathrm{mg} / \mathrm{L})$ & $5.1 \pm 0.26^{\mathrm{a}}$ & $5.8 \pm 0.35^{\mathrm{a}}$ & $6.4 \pm 0.21^{\mathrm{a}}$ \\
\hline $\mathrm{pH}$ & $8.5 \pm 0.61^{\mathrm{a}}$ & $8.9 \pm 0.72^{\mathrm{a}}$ & $8.2 \pm 0.49^{\mathrm{a}}$ \\
\hline $\mathrm{PO}_{4}(\mathrm{mg} / \mathrm{L})$ & $0.09 \pm 0.26^{\mathrm{b}}$ & $0.04 \pm 0.56^{\mathrm{c}}$ & $0.15 \pm 0.17^{\mathrm{a}}$ \\
\hline Ammonium (mg/L) & $0.04 \pm 0.07 \mathrm{c}$ & $0.05 \pm 0.14 \mathrm{~b}$ & $0.09 \pm 0.11 \mathrm{a}$ \\
\hline Primary Productivity ( g C/m3/h ) & $1.13 \pm 0.55 \mathrm{a}$ & $1.19 \pm 0.74 \mathrm{a}$ & $1.05 \pm 0.70 \mathrm{a}$ \\
\hline Gross productivity ( g C/m3/h) & $1.25 \pm 2.57 \mathrm{a}$ & $1.31 \pm 2.17 \mathrm{a}$ & $1.28 \pm 2.11 \mathrm{a}$ \\
\hline Respiration (mg C/L/three hours) & $0.53 \pm 0.22 \mathrm{a}$ & $0.56 \pm 0.27 \mathrm{a}$ & $0.62 \pm 0.45 \mathrm{a}$ \\
\hline
\end{tabular}

Means in the same row with different superscripts are significantly different at $\mathrm{p}<$ 0.05

The concentration of these variables wereranged between $5.1 \pm 0.26$ $6.4 \pm 0.21 \mathrm{mg} / \mathrm{L}$ throughout the culture (Table 2), and were within the optimum range and higher than $5 \mathrm{mg} / \mathrm{L}$ which reported by Boyd (1998) as the minimum desirable DO level in fish ponds. These are in agreement with results obtained byHussein (2009) and Ponce Palafox (2010). Concentrationsof dissolved oxygen in water was found above the minimum reported for these species $(3.25 \mathrm{mg} / \mathrm{L})$ in the region by Gonzalez et al. (2002), without affecting the growth of carp.

$\mathrm{pH}$ values ranged between $8.2 \pm 0.49$ (T3) and $8.9 \pm 0.61$ (T2) and were insignificantly $(\mathrm{P} \leq 0.05)$ influenced by the experimental treatments and this is in agreement with Boyd (1998) and Hussein (2009). Boyd (1990) reported that the application of ammonium and urea-based fertilizers can cause acidification of pond water because of nitrification, which produces two hydrogen ions from each ammonium ion. The orthophosphours $\left(\mathrm{PO}_{4}-\mathrm{mg} \mathrm{P} / \mathrm{l}\right)$ concentrations were fluctuated between $0.04 \pm 0.56$ and $0.15 \pm 0.17 \mathrm{mg} / \mathrm{l}$ and were significantly $(\mathrm{P} \leq 0.05)$ influenced by the experimental treatments. Ammonia concentrations $\left(\mathrm{NH}_{4}-\mathrm{mgN} / \mathrm{l}\right)$ were insignificantly $(\mathrm{P} \leq 0.05)$ influenced by the experimental treatments and they ranged between $0.04 \pm 0.07$ and $0.09 \pm 0.14 \mathrm{mg} / \mathrm{l}$. These results show a slight increase in ammonia concentration with the increase of $\mathrm{pH}$, which were in agreement with Hussein (2009). He reported ammonia concentrations of $(0.22-0.30 \mathrm{mg} / \mathrm{L})$ in ponds fertilized with cow manure and inorganic fertilizers. Low concentrations of ammonia may be attributed to ammonia utilization by phytoplankton (Boyd, 1998) or oxidation of ammonia nitrite especially in high dissolved oxygen level conditions (Boyd, 2000). Total ammonia nitrogen fluctuated throughout the experiment but remained below 1 $\mathrm{mg} / \mathrm{L}$ at the $\mathrm{pH}$ levels observed. Unionized ammonia probably did not adversely affect fish performance. Major water quality parameters measured during the present study remained in the favorable range for fish culture Boyd (1990) suggested that fish growth performance was not limited by any of water quality parameters. Comparable results were obtained by Hussein (2009). Even though the values of physico-chemical characteristics of water ponds during the experimental period were within the acceptable limits for carps as indicated by Miranda-filho et al., (1996).

The phytoplankton, productivity and respiration were representative for the open waters of the whole ponds. Chlorophytes were the dominant phytoplankton group in the culture ponds throughout the experiment. They were followed by the Bacillariophytes and Cianophytes (Table 3). Padmavathi and Prasad (2009); Hussein 
(2009) and Ponce Palafox (2010) in carp ponds found that the major groups of phytoplankton present were also those reported in this study. There was high concentration of Cianophytes, Chlorophytes, Euglenophytes and Bacilariophytes in cow manure, and Chlorophytes in sheep manure and mineral fertilizer. Phytoplankton was represented by 40 genera, 16 of which were found more frequently in the system. Debeljak and Adamek (1994) and Ponce Palafox (2010) found that the structure of phytoplankton in fish ponds with the poultry fertilizer made up 131 species, and in the fish ponds treated with the mineral fertilizer 105 species. Relative abundance of plankton was changed with time. Chlorophytes being the most dominant species in the cold season and Bacil ariophytes and Cianophytes in the warm season. The dominant species was Chlorophytes with significant difference $(\mathrm{p}<0.05)$.

The Use of inorganic and organic fertilizers improved water quality through stimulation of natural food, mainly phytoplankton and zooplankton, suitable for the filter feeding carp species. Organic fertilizers act as an energy source for bacterial growth, but the aerobic decomposition of organic matter by bacteria was an important drain of oxygen supplies in ponds (Boyd, 1982). Both phytoplankton and zooplankton biomass were significantly higher in ponds with improved fertilization compared to ponds with poor nutrition. Total ammonia nitrogen varied throughout experiment but remained below $1 \mathrm{mg} / \mathrm{L}$ at the $\mathrm{pH}$ levels observed. Major water quality parameters measured during the study remained in the favorable range for fish culture (Boyd, 1990), suggesting that cultured fish growth performance was not limited by any of the water quality parameters. Comparable results were obtained by Lawson (1995); Hussein (2009) and Ponce Palafox (2010).

Table 3: Phytoplankton groups (cells/mL) on carp ponds.

\begin{tabular}{|l|l|l|l|}
\hline Group & \multicolumn{1}{|c|}{$\begin{array}{c}\text { T1 } \\
\text { Sheep manure }\end{array}$} & \multicolumn{1}{c|}{$\begin{array}{c}\text { T2 } \\
\text { Cow manure }\end{array}$} & \multicolumn{1}{c|}{$\begin{array}{c}\text { T3 } \\
\text { Mineral fertilizer }\end{array}$} \\
\hline Cianophytes & $288,730^{\mathrm{b}}$ & $395,590^{\mathrm{a}}$ & $252,470^{\mathrm{c}}$ \\
Chlorophytes & $987,570^{\mathrm{a}}$ & $445,986^{\mathrm{b}}$ & $394,230^{\mathrm{c}}$ \\
Euglenophytes & $89,110^{\mathrm{c}}$ & $175,050^{\mathrm{a}}$ & $154,650^{\mathrm{b}}$ \\
Bacilariophytes & $459,316^{\mathrm{a}}$ & $399,790^{\mathrm{b}}$ & $283,280^{\mathrm{c}}$ \\
Total & $1,824,726^{\mathrm{a}}$ & $1,416,416^{\mathrm{b}}$ & $1,084,630^{\mathrm{c}}$ \\
\hline
\end{tabular}

Means in the same row with different superscripts are significantly different at $p<0.05$

These conditions seem to be good for the growth of fish species, especially for the filter-feeding ones. It was found that in ponds fertilized with sheep and cow manures higher concentrations of phytoplankton were shown $(1,824,726$ and $1,416,416$ cells $/ \mathrm{ml}$, respectively) that are significantly $(\mathrm{p}<0.05)$ higher than in ponds where chemical fertilizer was applied $(1,084,630$ cells $/ \mathrm{ml})$. These concentrations of phytoplankton are higher than those reported by Molina-Astudillo et al. (2003) and Ponce Palafox (2010) in carp ponds fertilized with cow manure $(17,008$ to 630,731 cells/ml and 1,157,706, 945,940 and 744,560 cells/ml). Noriege-Curtis (1979) reported that fish production in intensively manured ponds was not exclusively due to primary production, but also to heterotrophic production. Net primary productivity in organic fertilized ponds in Hondoras was significantly greater than in inorganic fertilized ponds (Green et al.,1989a \& b and 1990a and Ponce Palafox, 2010).

Respiration was evaluated by means of light and dark bottles, with an average value from 0.53 to $0.62 \mathrm{mg} \mathrm{C} / \mathrm{L} /$ three hours (25\% gross photosynthesis). Respiration had a similar trend in animal manure treatments .Gross photosynthesis maintained an increasing tendency of 0.95 to $1.0 \mathrm{mgC} / \mathrm{L} /$ three hours and primary productivity with values fluectuated between 1.05 and $1.19 \mathrm{mgC} / \mathrm{L} /$ three hours. Primary productivity 
revealed a differential pattern between organic manures and mineral fertilizers. These are in agreement with results of Ponce Palafox (2010).

In the present study, the final average biomass $(\mathrm{kg})$ yield of carp was significantly ( $\mathrm{p}<0.05)$ more in mineral fertilizer ponds $(2370.6 \mathrm{~kg} / \mathrm{fed}$.) than in cow (1948.8 kg/fed.) and sheep (1687.4 kg/fed.) manure ponds (Table 4).

Table 4: Production, yield and survival data in carp polyculture.

\begin{tabular}{|l|l|l|l|}
\hline Parameter & \multicolumn{1}{|c|}{$\begin{array}{c}\text { T1 } \\
\text { Sheep manure }\end{array}$} & \multicolumn{1}{|c|}{$\begin{array}{c}\text { T2 } \\
\text { Cow manure }\end{array}$} & \multicolumn{1}{c|}{$\begin{array}{c}\text { T3 } \\
\text { Mineral fertilizer }\end{array}$} \\
\hline Surface area $\left(\mathrm{m}^{2}\right)$ & $4200 \pm 170 \mathrm{a}$ & $4200 \pm 210 \mathrm{a}$ & $4200 \pm 180 \mathrm{a}$ \\
Number of fish / pond & 10,000 & 10,000 & 10,000 \\
Av. Biomass initial $(\mathrm{kg}):$ & $285.3 \pm 1.82 \mathrm{a}$ & $292.6 \pm 1.44 \mathrm{a}$ & $287.2 \pm 1.3 \mathrm{a}$ \\
$\quad$ Grass carp $(20 \%)$ & $34.2 \times 2000=68.4$ & $33.6 \times 2000=67.2$ & $34.4 \times 2000=68.8$ \\
Silver carp $(15 \%)$ & $28.1 \times 1500=42.15$ & $27.9 \times 1500=41.85$ & $28.7 \times 1500=43.05$ \\
Bighead carp $(15 \%)$ & $24.5 \times 1500=36.75$ & $26.7 \times 1500=40.05$ & $27.2 \times 1500=40.8$ \\
Common carp $(50 \%)$ & $27.6 \times 5000=138$ & $28.7 \times 5000=143.5$ & $26.9 \times 5000=134.5$ \\
Av. Biomass final $(\mathrm{kg})$ & $1687.4 \pm 133.3 \mathrm{c}$ & $1948.8 \pm 193.4 \mathrm{~b}$ & $2370.6 \pm 85.7 \mathrm{a}$ \\
Av. Fish yield (kg/fed./day) & $7.79 \pm 1.95 \mathrm{a}$ & $9.20 \pm 1.24 \mathrm{~b}$ & $11.57 \pm 0.67 \mathrm{a}$ \\
\hline
\end{tabular}

Means in the same row with different superscripts are significantly different at $p<0.05$

Data showed that the different fish species cultured in polyculture system performed better in treatment 3 (inorganic fertilization) followed by treatment 2 (cow manure), while lowest growth was observed in treatment 1 (sheep manure). Similar observations were detected by Ponce Palafox (2010). Pond fertilization plays an important role in meeting nutrient deficiency as well as stimulating plankton production and functioning through autotrophic and heterotrophic pathways (Bhakta et al., 2004; Sahu et al., 2007; Hussein, 2009 and Ponce Palafox, 2010).

Results revealed that the total average fish yield ( $\mathrm{kg} / \mathrm{fed} . /$ day) gains of carps in three treatments were $7.79,9.20$ and $11.57 \mathrm{~kg} /$ fed./ day, respectively. This revealed that the total weight gain of carp was greater in T3 and T2 followed by T1. Lower value was found in $\mathrm{T} 1$, which was different from the three treatments.

In general, the final biomass obtained from 1687.4 to $2370.6 \mathrm{~kg} / \mathrm{fed}$. was within that reported by Gonzalez et al. (2002) Hussein (2009) and Ponce Palafox (2010) for carp polyculture without supplemental feed

Added manure or fertilizer had a positive effect (Vromant et al., 2002) on the dissolved oxygen, phytoplankton and primary productivity. All the treatments did not degrade the physico-chemical properties of water (Ponce-Palafox et al., 1994). The sheep and cow manures cause wide fluctuations in the water quality, mainly dissolved oxygen concentration which is shown in the largest standard deviations of 5.8 and 6.4 $(\mathrm{mg} / \mathrm{L})$ for sheep and cow fertilizers, respectively, and lower in the mineral fertilizer $(5.1 \mathrm{mg} / \mathrm{L})$. The ammonium was significantly higher in the mineral fertilizer $(0.09$ $\mathrm{mg} / \mathrm{L}$ ). Information about the potential production level of a fertilized fishpond is indispensable for its rational management. From the data collected by Barbe et al. (1999) statistical treatment evidenced relationships between phytoplankton types, chlorophyll a densities and fish production levels. Combining both five typical groups of phytoplankton and five different concentrations of chlorophyll a arranged into a grid, it was possible to determine the potential fish production of the ponds (up to over $2000 \mathrm{~kg} / \mathrm{fed}$.).

In general, an inverse relationship was found between the abundance of phytoplankton and fish yield and a direct relationship appeared between yield and concentrations of dissolved oxygen in pond water. The general conditions were adequate to obtain high yields without commercial feeds (2.0 ton/fed.), higher than those 
found in temperate regions ( $0.72 \mathrm{ton} / \mathrm{Ha})$ of Europe (Nikolova et al., 2008a\&b) and the application of organic manures can be recommended because of their availability and low cost.

\section{REFERENCES}

Abdel-Tawwab, M.; Abd El-ghany, AE. and Ahmad, MH. (2007). Effect of diet supplementation on water quality, phytoplankton community structure, and the growth of Nile tilapia, Oreochromis niloticus (L.), common carp, Cyprinus carpio L., and silver carp, Hypophthalmichthys molitrix V. polycultured in fertilized earthen ponds.J Appl. Aquacult.,19:1-24.

Afzal, M.; Rub, A.; Akhtar, N.; Khan, M.F.; Barlas, A. and Qayyum, M. ( 2007). Effect of organic and inorganic fertilizers on the growth performance of bighead carp (Aristicthys nobilis) in polyculture system. Int. J. Agric. Biol., 9: 931-933

AOAC. (1994). Association of Official Analytical Chemists. Official Methods of Analysis. $14^{\text {th }}$ Edn., Arlington, VA., pp: 114.

APHA. (1995). American Public Health Association. Standard methods for the examination of water and wastewater, $16^{\text {th }}$ edition American Public Health Association, Washington, D.C.

Arredondo-Figueroa JL. and Juarez, R. (1986). Manual para el cultivo de Carpas. México, D.F. Secretaría de Pesca. 121.

Arredondo, JL. and Ponce, JT. (1998). La calidad del agua en acuicultura: Conceptos y Aplicaciones. México D.F.: AGT Editors. S. A. 250.

Bhakta, J. N.; Sarkar, D.; Jana, S. and Jana, B. B. (2004). Optimizing fertilizer dose for rearing stage production of carps under polyculture. Aquacult., 239: 125-139.

Bhakta, J. N.; Bandyopadhyay, P. K. and Jana, B. B. (2006). Effect of different doses of mixed fertilizer on some biogeochemical cycling bacterial population in carp culture pond. Tur. J. Fish. Aqua. Sci., 6: 165-171.

Barbe, J.; Schlumberger, O. and Bouretz, N. (1999). Utilisation du phytoplancton pour estimer la production piscicole potentielle des étangs. Bulletin Francais de la Peche et de la Pisciculture, 355:387-402.

Boyd, C. E. (1982). Water Quality Management For Pond Fish Culture. Elsevier Scientific Publishing Company, New York, NY, 318 pp.

Boyd, C. E. (1990). Water quality in ponds for aquaculture. Alabama Agriculture Experiment Station Auburn Univ, Alabama, Birmingham Publishing Co. $482 \mathrm{pp}$.

Boyd, C. E. (1998). Water quality for pond aquaculture. Research and development series No. 43. pp37. International Center for Aquaculture and Aquatic Environments.Alabama Agriculture Experiment Station. Auburn Univ.

Boyd, C. E. (2000). Water Quality: An Introduction. Kluwer Academic published Bosto, Massachusetts.

Debeljak, L. and Adamek, Z. (1994). Utjecaj gnojidbe na razvoj phytoplankton u saranskim mladicnjacima. Ribarstvo, 52: 3-16.

Dhawan, A. and Kaur, S. (2002). Pig dung as pond manure: Effect on water quality, pond productivity and growth of carps in polyculture system. Naga [Naga ICLARM Q.]; 25: 11-14.

Duncan, D.B. (1955).Multiple-range and multiple F tests. Biometrics, 11:1-42. 
EIFAC, (1980) .European Inland Fisheries Advisory Commission. Report of a study group on the standardization of methodology in fish nutrition. Roma Italia: FAO. 24.

Green, B.W.; Alvarenga, H.R.; Phelps, R.P. and Espinoza, J. (1989a). Honduras Cycle III of the CRSP Global Experiment, pond Dynamics/Aquaculture CRSP Data Reports, Oregon state University, Corvallis.

Green, B. W.; Phelps, R. P. and Alvarenga, H. A. (1989b). The effect of manures and chemical fertilizers on the production of Oreochromis niloticus in earthen ponds. Aquaculture, 76:37-42.

Green, B.W.; Alvarenga, H.R.; Phelps, R. P. and Espinoza, J. (1990a). Honduras Cycle I of the CRSP Global Experiment, pond Dynamics / Aquaculture CRSP Data Reports, Oregon state University, Corvallis.

González, J. Auró de Ocampo A., Anislao, V. (2002). Evaluation of the common carp (Cyprinus carpio, var. communis) growth fed when ensiled pig feces. Veterinaria México; 33: 109-118.

Hepher, B. and Pruginin, Y. (1981). Comercial fish farming with special reference to fish culture in Israel. John Wiley and Sons, New York, 261.

Hussein,M.,S., (1995).Semi-intensive fish culture in some Egyptian fish farms. PH.D. Thesis, Faculty of Agri., Suez Canal Univ., 256pp

Hussein, M.S. and Abdel-Hakim N.F. (2003). Comparative study on efficiency of chemical fertilizers,manures and artificial feed as fish food in polyculture ponds. An. of Agri. Sc., Moshtohor, 41(1):179-193 .

Hussein, M.S. (2009). Comparative effects of fertilization and supplementary feed with rice bran on growth performance, water quality parameters and economic returns of the fish under polyculture ponds. J. Product. \& Dev. 15(3):251-277.

Islam, M.S. (2002). Evaluation of supplementary feed for semi-intensive pond culturemahseer,Tor putitora (Hamilton). Aquacult., 212: 263-276

Jana, B. B.; Chakrabarty P.; Biswas, J. K. and Ganguly, S. (2001). Biogeochemical cycling bacteria as indices of pond fertilization: Importance of CNP ratios of input fertilizers. J. Appl. Microbiol., 90:733-740

Javed, M.; Hassan, M. and Sial, M. B. (1992). Fish pond fertilization. IV: Effect of cowdung on the growth performance of major carps. Pakistan J. Agri. Sci., 29(2): 111-115.

Lawson, T. B. (1995). Fundamentals of aquaculture engineering.Chapman \& Hall.An International Thomson Publishing Company.New York. USA.

Miranda-Filho, K. C.; Wasielesky,W. Jr. and Macada, A. P. (1996). The effect of ammonia and nitrite on the growth of mullet, Mugil platanus (pisces, Mugilidae). Rev. Bras. Biol., 55:45-50

Molina AI; Granados, G. and Quiroz, H. (2003). Productividad primaria y crecimiento de carpas chinas en estanques rústicos. Acta Univ., 13: 66-74.

Moustaka, M. and Nikolaidis G. (1992). Phytoplankton and physical-chemical features of Tavropos reservoir Greece. Hydrobiologia, 228:141-149.

New, M. and Fedoruk, K.(2003). Reports on the Regional Workshop on Aquaculture Planning in Asia, Bangkok, Thialand, 154pp.

Nikolova, L.; Hadjinikolova, L.; Dochin, K.; Terziyski, D.; Atanasova, R. and Stoeva, A. (2008a). Carp fish rearing in autochthonous polyculture of one and the same age (Cyprinus Carpio L., Aristichthys Nobilis Rich. and Ctenopharyngodon Idella Val.). Bulgarian J. Agricult. Sci.; 14: 133-138. 
Nikolova, L.; Hadjinikolova, L.; Dochin, K.; Terziyski, D.; Atanasova, R. and Stoeva, A. (2008b). Carp fish rearing in autochthonous mixed polyculture (Cyprinus Carpio, L., Aristichthys nobilis and Ctenopharyngodon Idella Val.). Bulgarian J. Agricult. Sc., 14: 139-144.

Noriege-Curtis, P. (1979). Primary productivity and related fish yield in intensely manured fish ponds. Aquacult., 17:335-344.

Qin, J.; Culver, D. A. and Yu, N. (1995). Effect of organic fertilizer on heterotrophs and autotrophs; implication for water quality management. Aqua. Res., 26: 911-920.

Padmavathi, P. and Prasad, KD. (2009). Studies on the influence of plankton on fish production of carp culture ponds of Krishna district, Andhra Pradesh, India. Ecology Environment and Conservation;15:473-479.

Ponce, JT.; Arredondo, JL. and De La Lanza, G. (1994) .Effects of polyculture and fertilization on water quality in carp ponds. 1.Physico-chemical factors. Verhandlungen des Internationalen Verein Limnologie, 25: 1315-1317.

Ponce Palafox J. T. (2010). The effect of chemical and organic fertilization on phytoplankton and fish production in carp (Cyprinidae) polyculture system.

Revista Biociencias Julio (2010). Vol. 1 Núm. 1 Año 1 Páginas 44 a 50

Sahu, P.K.; Jena, V.; Das, P. C.; Mondal, S. and Das, R.( 2007). Production performance of Labeo calbasu (Hamilton) in polyculture with three Indian major carps Catla catla (Hamilton), Labeo rohita (Hamilton) and Cirrhinus mrigala (Hamilton) with provisions of fertilizers, feed and periphytic substrate as varied inputs. Aquacult., 262: 333-339

SAS. (2005). Statistical Analyses Systems. SAS Program ver.9.1, SAS institute incorporation, Cary, NC27513USA

Silva, S.S and AndersonT.A..(1995). Fish Nutrition in Aquaculture. Chapman and Hall Publication, New Delhi, India

Sun, W.,; Dong, S.; Zhao, X.; jie, Z.; Zhang, H. and Zhang, L. (2010). Effects of zooplankton refuge on the growth of tilapia (Oreochromis niloticus) and plankton dynamics in pond. Aquacult. Int., 18:647-655

Tabinda, A. B and Ayub, M. (2009).Effect of high phosphate fertilization rate on pond phosphate concentrations, chlorophyll a, and fish growth in carp polyculture. Aquacult. Int., 9: 9243-9249.2

Tabinda, A. B. and Ayub, M. (2010). Effect of high phosphate fertilization rate on pond phosphate concentrations, chlorophyll a, and fish growth in carp polyculture. Aquacult. Int., 18: 285-301

Tang, YA. (1970). Evaluation of balance between fishes and available fish food in multispecies fish culture ponds in Taiwan. Transactions of the American Fisheries Society; 99: 708-718.

Vadas, RL. (1992). The springtime phytoplankton of two calcareous ponds in Ohio. Journal Freshwatater Ecology, 7: 407-418.

Vromant, N.; Nam, C Q. and Ollevier, F. (2002). Growth performance and use of natural food by Oreochromis niloticus (L.) in polyculture systems with Barbodes gonionotus (Bleeker) and Cyprinus carpio (L.) in intensively cultivated rice fields. Aquacult. Res., 33: 969-978.

Wilkins, D. and Piedrahita, R. (1988). The relation between phytoplankton and dissolved oxygen in fish ponds. Aquacult., 68: 249-265. 


\section{Arabic Summary}

تأثير التسميد العضوى والكيماوى على أداء النمو , العوالق النباتية , و أنتاج الأسماك فى نظام الأستزراع متعدد الأنو اع للمبروك (الثبوطيات)

$$
\text { قسم الأنتاج الحيو انى (شعبة أنتاج الأسماك) بكلية الزين حسر اعة - جامعة الأز هر - مصر. }
$$

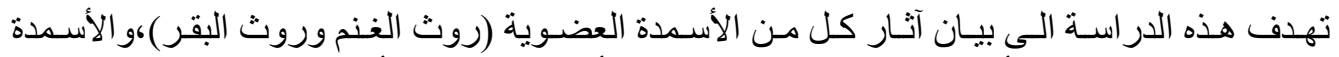

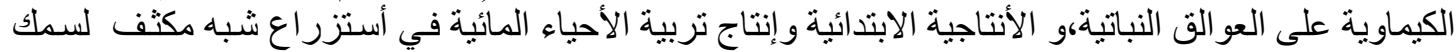

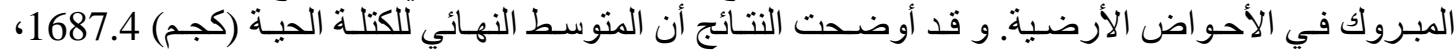

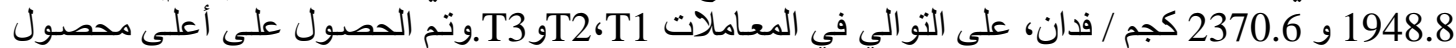

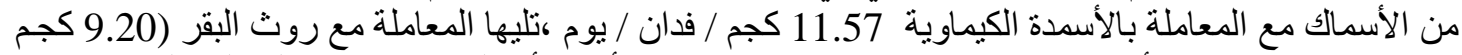

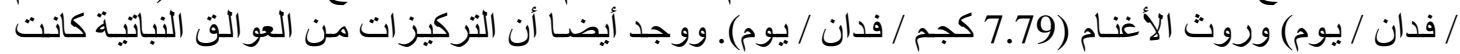

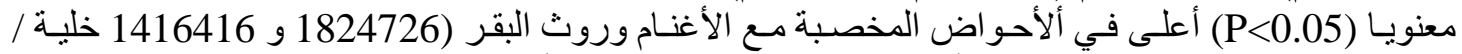

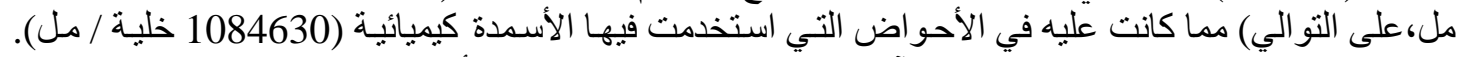

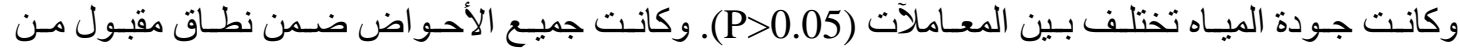
معاييرجودة المياه خلال هذه الدر استة.

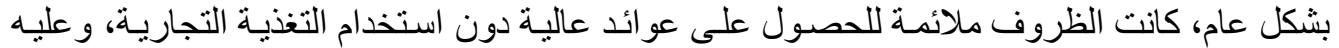

يمكن أن أوصى الدر اسة باستخدام الأسمدة العضوية بسبب تول الفر ها عا وتكلفتها المنخفضة. 